\title{
Feasibility and Safety of Repeat Instant Endovascular Interventions in Patients with Refractory Cerebral Vasospasms
}

\author{
(D) A. Andereggen, (D). Beck, (D)W.J. Z'Graggen, (D) G. Schroth, (D) R.H. Andres, (D) M. Murek, (D) M. Haenggi, (D) M. Reinert, (D)A. Raabe, and
} (D). Gralla

\begin{abstract}
BACKGROUND AND PURPOSE: For patients with cerebral vasospasm refractory to medical and hemodynamic therapies, endovascular therapies often remain the last resort. Data from studies in large cohorts on the efficacy and safety of multiple immediate endovascular interventions are sparse. Our aim was to assess the feasibility and safety of multiple repeat instant endovascular interventions in patients with cerebral vasospasm refractory to medical, hemodynamic, and initial endovascular interventions.
\end{abstract}

MATERIALS AND METHODS: This was a single-center retrospective study of prospectively collected data on patients with cerebral vasospasm refractory to therapies requiring $\geq 3$ endovascular interventions during the course of treatment following aneurysmal subarachnoid hemorrhage. The primary end point was functional outcome at last follow-up (mRS $\leq 2)$. The secondary end point was angiographic response to endovascular therapies and the appearance of cerebral infarctions.

RESULTS: During a 4-year period, 365 patients with aneurysmal subarachnoid hemorrhage were treated at our institution. Thirty-one (8.5\%) met the inclusion criteria. In 52 (14\%) patients, $\leq 2$ endovascular interventions were performed as rescue therapy for refractory cerebral vasospasm. At last follow-up, a good outcome was noted in 18 (58\%) patients with $\geq 3$ interventions compared with 31 (61\%) of those with $\leq 2$ interventions $(P=$ .82). The initial Hunt and Hess score of $\leq 2$ was a significant independent predictor of good outcome (OR, 4.7; 95\% $\mathrm{Cl}$, 1.2-18.5; $P=.03)$, whereas infarcts in eloquent brain areas were significantly associated with a poor outcome (mRS 3-6; OR, 13.5; 95\% Cl, 2.3-81.2; $P=.004$ ).

CONCLUSIONS: Repeat instant endovascular intervention is an aggressive but feasible last resort treatment strategy with a favorable outcome in two-thirds of patients with refractory cerebral vasospasm and in whom endovascular treatment has already been initiated.

ABBREVIATIONS: CVS = cerebrovascular vasospasm; GCS = Glasgow Coma Scale; HH = Hunt and Hess; IAN = intra-arterial nimodipine; PTA = percutaneous transluminal balloon angioplasty; RCVS $=$ refractory CVS

C erebral vasospasm (CVS) after aneurysmal subarachnoid hemorrhage remains a major cause of delayed cerebral ischemia and related morbidity and mortality. ${ }^{1,2}$ Standard treatment consists of hyperdynamic/hypertensive therapy and orally administered nimodipine to prevent ischemic events. ${ }^{3,4}$ Nevertheless,

Received April 21, 2016; accepted after revision October 11.

From the Department of Neurosurgery (L.A., J.B., W.J.Z., R.H.A., M.M., M.R., A.R.), Institute for Diagnostic and Interventional Neuroradiology (L.A., G.S., J.G.), Departments of Neurology (W.J.Z.), and Intensive Care Medicine (M.H.), Inselspital, Bern University Hospital, University of Bern, Switzerland.

The authors declare no conflict of interest. This study was approved by the Ethics Committee of the Canton of Bern, Switzerland (Kantonale Ethikkommission Bern, KEK, 177/14).

Paper previously presented in part at: Vasospasm 2013: The 13th International Conference on Neurovascular Events after Subarachnoid Hemorrhage, Lucerne, Switzerland; July 10-12, 2013.

Please address correspondence to Jan Gralla, MD, Director and Chairman, Institute of Diagnostic and Interventional Neuroradiology, Inselspital, Bern University Hospital, Freiburgstr 10, 3010 Bern, Switzerland; e-mail: jan.gralla@insel.ch

三 Indicates article with supplemental on-line tables.

http://dx.doi.org/10.3174/ajnr.A5024
$20 \%-30 \%$ of patients develop refractory CVS with cerebral infarction causing permanent neurologic deficits or death. ${ }^{5}$ In cases of severe CVS and threatened ischemia despite hemodynamic and medical treatment, no commonly accepted treatment guidelines exist. $^{6}$ Although endovascular methods offer some last resort treatment options, their use is generally not extended throughout the entire CVS course and application is limited to 1 or 2 or, at most, 3 interventions, resulting in an ambiguous functional outcome with most patients unable to resume work post-SAH. ${ }^{7-10}$

In this single-center audit of practice, we evaluated repeat immediate endovascular therapies in a subgroup of symptomatic patients with the most severe, refractory CVS during the vasospasm period.

\section{MATERIALS AND METHODS}

\section{Patient Inclusion Criteria and Study End Points}

To comply with the inclusion criteria, patients with proved aneurysmal subarachnoid hemorrhage had to fulfill the requirement of medically and hemodynamic refractory CVS (rCVS) necessitating $\geq 3$ endovascular interventions during 
the CVS period. These patients were compared with a cohort of patients with aneurysmal subarachnoid hemorrhage necessitating 1-2 endovascular interventions during the refractory CVS period. Patients with mycotic aneurysms were excluded from the study. The primary end point was functional outcome at last follow-up (modified Rankin Scale $\leq 2$ ). The secondary end point was angiographic response to endovascular therapies and the appearance of cerebral infarctions.

\section{Management of CVS}

After early aneurysm treatment ( $\leq 24$ hours with either clip or coil embolization), patients were continuously monitored in the intensive care unit and kept normovolemic with blood pressure at normal high levels. A daily check was made of electrolytes (ie, sodium), and an assessment with transcranial Doppler was performed. Medical therapy consisted of nimodipine administered by the enteral route (60 mg every 4 hours for 21 days). In conscious patients, immediate endovascular therapy was indicated in cases of symptomatic rCVS, defined as the appearance of a new neurologic deficit despite medical and hemodynamic treatment (ie, hyperdynamic/hypertensive therapy) or a decline in consciousness not resulting from hydrocephalus (ie, an NIHSS score increase of $\geq 2$ and/or a Glasgow Coma Scale [GCS] score decrease of $\geq 2$ ). In unconscious patients, rising transcranial Doppler mean velocities of $\geq 150 \mathrm{~cm} / \mathrm{s}$ or increased flow velocity of $\geq 50$ $\mathrm{cm} / \mathrm{s}$ during 24 hours was considered an indication for endovascular treatment in cases in which the CT perfusion scan or MR imaging showed a mean transit time of $>5.9$ seconds. ${ }^{11}$ Other indications for endovascular rescue therapies included patients with marked changes in brain-tissue oxygen pressure values $(<15$ $\mathrm{mm} \mathrm{Hg}$, Licox Brain Oxygen Monitoring System [Integra LifeSciences, Saint Priest, France]) who were not responding to medical and hemodynamic therapies when the MR imaging showed a diffusion-perfusion mismatch. ${ }^{12,13}$

\section{Endovascular Interventions}

Intra-arterial nimodipine (IAN) with continuous infusion was delivered locally through a 0.18 -inch microcatheter (Renegade Hi-Flo; Boston Scientific, Natick, Massachusetts) into the most affected intracranial vessel segments. A dose of $2.5 \mathrm{mg}$ of nimodipine was administered at the most proximal site of each spastic artery $(12 \mathrm{~mL}$ in $38-\mathrm{mL}$ saline, administered at $20-30 \mathrm{~mL}$ per hour for 30 minutes). Repeat angiography was performed 30 minutes after IAN to evaluate the response of the spastic vessels. In cases of poor response to IAN, percutaneous transluminal balloon angioplasty (PTA) was performed by using intracranial balloon catheters (Gateway; Stryker, Kalamazoo, Michigan). Balloon diameter and inflation pressure were chosen according to the target vessel diameter before vasospasm. "Angiographic CVS" was defined as narrowing of the arterial diameter by $\geq 30 \%$ from the baseline diameter, as assessed by 2 experienced interventional neuroradiologists (G.S., J.G.).

\section{Neurologic Outcome}

The immediate response to IAN and/or PTA was evaluated by neurosurgeons and critical care physicians. In those patients who did not respond, MR imaging was performed. In cases of confirmed multiple ischemic areas without any salvageable penum- bra, therapy was suspended. ${ }^{14,15}$ Complications resulting from $\mathrm{SAH}$, obliteration procedures, and multiple interventions were recorded separately according to the clinical protocol. Neurologic outcome was assessed by mRS, the GCS, and Glasgow Outcome Scale at discharge and at the last follow-up. ${ }^{5}$ For patients who lacked long-term follow-up data, the mRS was assessed via telephone interview. ${ }^{16}$ The patients' morbidity and reintegration into the workplace at last follow-up were documented.

\section{Assessment of Stroke}

Radiologic ischemia was documented with CT or MR imaging. ${ }^{17}$ Twenty-four hours following radiologic or surgical aneurysm obliteration, a cerebral CT scan was obtained in all patients to look for treatment-related ischemia. CT scans or MR imaging at the time of patient discharge allowed the visualization of new stroke areas resulting from CVS during the clinical course. Associated functional deficits were registered.

\section{Statistical Methods}

Data were analyzed by using SPSS statistical software, Version 21.0 (IBM, Armonk, New York). Clinical outcome was dichotomized into favorable ( $m R S \leq 2)$ and poor outcome ( $m R S \geq 3$ ). Data are given as mean \pm SD unless otherwise stated. For comparisons of means between the 2 analysis groups (ie, $<2$ interventions versus $\geq 3$ interventions), the Student $t$ test was used for normally distributed data (comparing patient age and follow-up time), and the Mann-Whitney $U$ test, for skewed or non-normal data (comparing the number of treatments, vessel segments treated, and vascular territories). The other categoric variables were compared between the 2 analysis groups by using the Pearson $\chi^{2}$ test or the Fisher exact test, as appropriate (Tables 1 and 2). To identify predictors of good functional outcome ( $\mathrm{mRS} \leq 2)$, we performed multivariable analysis with a binary logistic regression model, including the following variables: patient age, sex, Hunt and Hess $(\mathrm{HH})$ grade after $\mathrm{SAH}$, the number of treatments, the number of vessels treated, the number of vascular territories, aneurysm location, further aneurysms, aneurysm obliteration, necessity for PTA, cerebral infarcts, and length of follow-up. Odds ratios and $95 \% \mathrm{CI}$ were calculated. $P$ values $\leq .05$ were considered statistically significant.

\section{RESULTS}

\section{Patient Demographics}

During the 4-year study period, 365 patients with aneurysmal SAH were admitted to our institution. Thirty-one (8.5\%) met the inclusion criteria with $\geq 3$ endovascular interventions during the CVS period. In 52 patients with aneurysmal SAH, 1-2 endovascular interventions were performed during the CVS period. Patient characteristics did not differ significantly between the 2 cohorts and are summarized in Table 1 (see also On-line Table 1). Mean age was 54 years (range, 24-77 years), and 66 (80\%) were women. Forty-five (54\%) patients presented with a Hunt and Hess grade of $\geq 3 .{ }^{18}$ At admission, a mild GCS score of $14-15$ was noted in $42 \%$ of patients; a moderate score (GCS, 9-13), in 21\%; and a severe score (GCS, 3-8), in 38\%. Most patients (92\%) presented with a Fisher grade $3^{19}$ at clinical onset. Patients with aneurysms not suitable for coil embolization were treated with clip 
Table 1: Characteristics of patients with cerebral vasospasm treated with $\geq 3$ interventions compared with those treated with $\leq 2$ interventions

\begin{tabular}{|c|c|c|c|c|}
\hline Characteristics & $\begin{array}{l}\text { Group I: } 1 \text { or } 2 \\
\text { Interventions }\end{array}$ & $\begin{array}{l}\text { Group II: 3-6 } \\
\text { Interventions }\end{array}$ & All Patients & $P$ Value \\
\hline Cases (No.) (\%) & $52(63)$ & $31(37)$ & $83(100)$ & \\
\hline Age (mean) (range) (yr) & $55.5 \pm 11.3,24-75$ & $52.1 \pm 8.6,34-77$ & $54.2 \pm 10.5,24-77$ & .158 \\
\hline Women (No.) (\%) & $42(81)$ & $24(77)$ & $66(80)$ & .782 \\
\hline \multicolumn{5}{|l|}{ Hunt and Hess grade (No.) (\%) } \\
\hline $\mathrm{HH}$ scale $\leq 2$ & $27(52)$ & $11(36)$ & $38(46)$ & .176 \\
\hline $\mathrm{HH}$ scale $\geq 3$ & $25(48)$ & $20(64)$ & $45(54)$ & .176 \\
\hline Fisher grade 3 (No.) (\%) & $46(89)$ & $30(97)$ & $76(92)$ & .248 \\
\hline \multicolumn{5}{|l|}{ GCS at admission } \\
\hline Mild & $21(41)$ & $13(42)$ & $34(42)$ & .999 \\
\hline Moderate & $8(16)$ & $9(29)$ & $17(21)$ & .162 \\
\hline Severe & $22(43)$ & $9(29)$ & $31(38)$ & .245 \\
\hline \multicolumn{5}{|l|}{ Aneurysms location (No.) (\%) } \\
\hline Anterior & $33(64)$ & $21(68)$ & $54(65)$ & .813 \\
\hline Posterior & $19(36)$ & $10(32)$ & $29(35)$ & .813 \\
\hline Multiple aneurysms & $17(33)$ & $13(42)$ & $30(36)$ & .481 \\
\hline \multicolumn{5}{|l|}{ Aneurysm obliteration } \\
\hline Clipping & $19(36)$ & $5(16)$ & $24(29)$ & .078 \\
\hline Coiling & $33(64)$ & $26(84)$ & 59 (71) & .078 \\
\hline Intracerebral hemorrhage & $7(14)$ & $9(29)$ & $16(20)$ & .15 \\
\hline \multicolumn{5}{|l|}{ Intra-arterial spasmolysis } \\
\hline No. of treatments (mean) (range) & $78(1.5 \pm 0.5,1-2)$ & $132(4.3 \pm 1.6,3-10)$ & $210(2.5 \pm 1.7,1-10)$ & $<.001$ \\
\hline $\begin{array}{l}\text { No. of vessel segments treated } \\
\text { (mean) (range) }\end{array}$ & $152(2.9 \pm 1.5,1-6)$ & $298(9.6 \pm 6.6,4-40)$ & $450(5.4 \pm 5.3,1-40)$ & $<.001$ \\
\hline $\begin{array}{l}\text { No. of vascular territories } \\
\text { (mean) (range) }\end{array}$ & $85(1.6 \pm 0.7,1-3)$ & $72(2.3 \pm 0.8,1-3)$ & $157(1.9 \pm 0.8,1-3)$ & $<.001$ \\
\hline PTA (No.) (\%) & $9(17)$ & $17(55)$ & $26(31)$ & .001 \\
\hline Vessel dissections (No.) (\%) & $1(2)$ & $5(16)$ & $6(7)$ & .03 \\
\hline $\begin{array}{l}\text { Follow-up (mean) (median) } \\
\text { (range) (mo) }\end{array}$ & $12 \pm 8.7,10,1-24$ & $10 \pm 6.3,9,2-22$ & $11 \pm 7.9,10,1-24$ & .316 \\
\hline
\end{tabular}

Table 2: Primary and secondary outcome measurements following multiple interventions

\begin{tabular}{lcccc}
\hline \multicolumn{1}{c}{ Outcome } & $\begin{array}{c}\text { Group I: } 1 \text { or } 2 \\
\text { Interventions }\end{array}$ & $\begin{array}{c}\text { Group II: 3-6 } \\
\text { Interventions }\end{array}$ & $\begin{array}{c}\text { All } \\
\text { Patients }\end{array}$ & $\boldsymbol{P}$ Value \\
\hline $\begin{array}{l}\text { mRS } \leq 2 \text { at discharge (No.) (\%) } \\
\text { mRS } \leq 2 \text { (good outcome) at last FU }\end{array}$ & $16(31)$ & $5(16)$ & $21(25)$ & .193 \\
$\quad$ (No.) (\%) & $31(61)$ & $18(58)$ & $49(60)$ & .821 \\
mRS 3-5 (poor outcome) at last & $13(26)$ & $4(13)$ & $17(21)$ & .262 \\
$\quad$ FU (No.) (\%) & & & & \\
$\begin{array}{l}\text { Persistent disabilities requiring constant } \\
\text { nursing care (mRS 4 and 5) (No.) (\%) }\end{array}$ & $4(8)$ & $3(10)$ & $7(9)$ & .999 \\
$\begin{array}{l}\text { Mortality (No.) (\%) } \\
\text { Infarcts in eloquent brain areas (No.) (\%) }\end{array}$ & $7(14)$ & $9(29)$ & $16(20)$ & .149 \\
Brain infarcts (No.) (\%) & $26(52)$ & $23(74)$ & $49(61)$ & .062 \\
\hline
\end{tabular}

Note:-FU indicates follow-up.

reconstruction (29\% of patients) based on interdisciplinary review. Thirty-six percent of patients presented with multiple aneurysms. In $65 \%$ of patients, the ruptured aneurysm was located in the anterior, and in 35\%, in the posterior circulation. In 51 patients $(63 \%)$, an external ventricular drain was inserted due to acute hydrocephalus.

\section{Endovascular Interventions}

The number of treatments, vessel segments treated, and vascular territories and the requirement for PTA were significantly higher in patients with $\geq 3$ interventions than in patients with $\leq 2$ interventions (Table 1). Endovascular treatment for CVS was performed between 3 and 15 days after the initial ictus (mean, 6 days). The mean clinical course of vasospasm lasted for $4.8 \pm 2.8$ days (range, 1-14 days); in 15 patients (48\%), it lasted for $>5$ days. A total of 210 (mean, $2.5 \pm 1.7$ per patient) endovascular interventions were per- formed (mean, $4.3 \pm 1.6$ in patients with $\geq 3$ interventions, versus mean, $1.5 \pm 0.5$ in patients with $\leq 2$ interventions; $P<$ $.001)$, resulting in the treatment of 450 vessel segments (mean, $5.4 \pm 5.3$ per patient; range, 1-40 segments; mean, $9.6 \pm$ 6.6 in patients with $\geq 3$ interventions, versus mean, $2.9 \pm 1.5$ in patients with $\leq 2$ interventions; $P<.001)$, and 157 vascular territories (mean, $1.9 \pm 0.8$ per patient; range, $1-3$; mean, $2.3 \pm 0.8$ in patients with $\geq 3$ interventions, versus mean, $1.6 \pm$ 0.7 in patients with $\leq 2$ interventions; $P<$ .001). A moderate immediate angiographic effect (arterial dilation $<30 \%$ ) was observed after IAN in $26(31 \%)$ interventions, and consecutive transluminal PTA was applied in these cases, namely in 9 (17\%) patients with $\leq 2$ interventions versus 17 (55\%) patients with $\geq 3$ interventions $(P=.001)$. In the cohort of patients with $\geq 3$ interventions, 13 (42\%) underwent 3 treatment sessions, 8 (26\%) underwent 4 sessions, 4 (13\%) underwent 5 sessions, and 4 (13\%) underwent 6 sessions (Fig 1). One patient had a total of 7 treatment sessions, and another, 10 sessions during the CVS course. Of the 52 patients with $\leq 2$ interventions, $26(50 \%)$ underwent 1 treatment session and 26 (50\%), 2 sessions.

\section{Functional Outcome}

Functional outcome was recorded at discharge (mean, 3 weeks; range, 2-6 weeks) and after a median follow-up at 10 months 

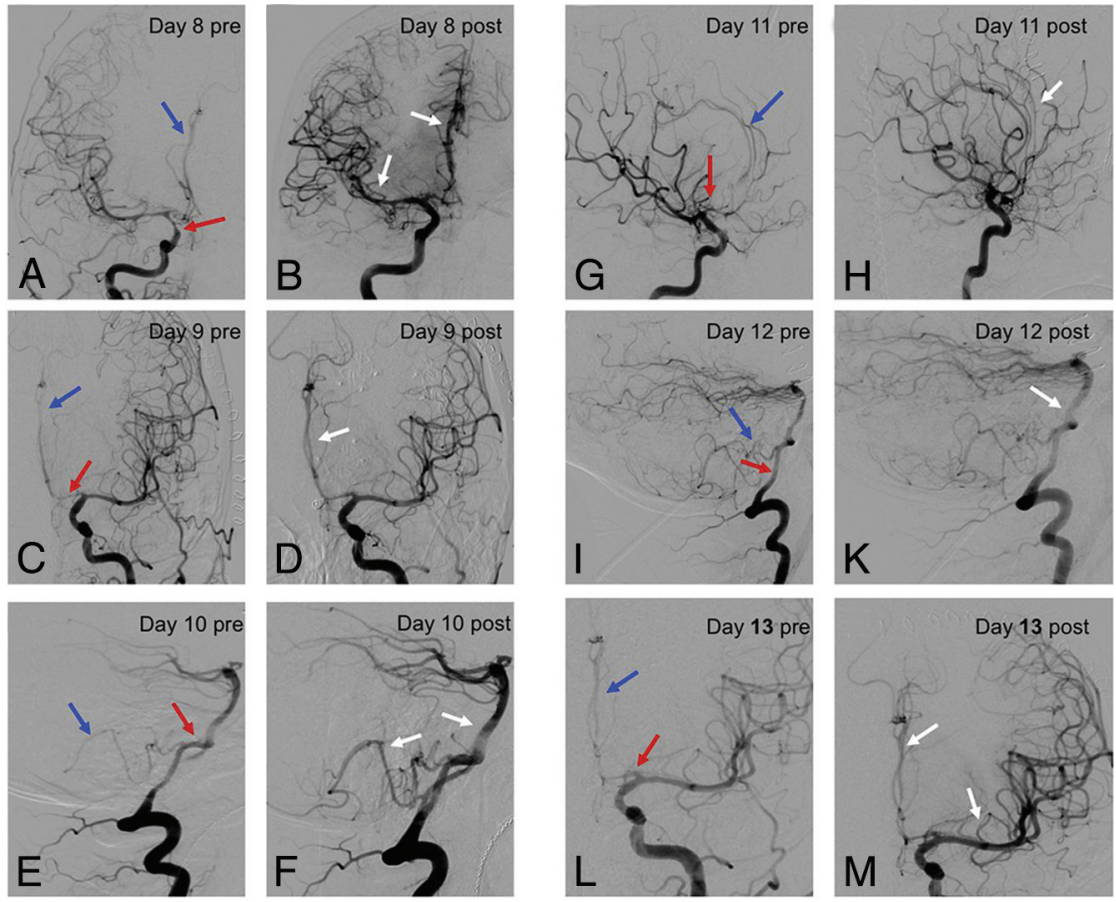

FIG 1. Repeat angiograms in refractory cerebral vasospasms. Repeat angiograms (red arrows: proximal spastic vessels; blue arrows: distal spastic vessels) in a 41-year-old woman with a ruptured anterior communicating artery aneurysm initially treated with coil embolization. On day 8 after the ictus, the patient presented with hemiparesis on the left side. A, ICA angiogram, anteroposterior view, shows vasospasm of the right-sided $\mathrm{M} 1$ and $\mathrm{A} 1 / \mathrm{A} 2$ segments. $B, \mathrm{ICA}$ angiogram of the same patient after nimodipine infusion demonstrates reduced vasospasm of the $\mathrm{Ml}$ and $\mathrm{Al} / \mathrm{A} 2$ segments, with improved perfusion of both the proximal and distal arteries. $C-M$, Corresponding angiograms of the anterior circulation $(C, D, G, H, L, M)$ and posterior circulation $(E, F, I$, $K$ ) in the same patient during the CVS period from day 9 to day 13 . Images on the right side show the effect after IAN. Note the effect of nimodipine infusion on the vessel diameter (white arrows).

(range, 1-24 months; Table 2 and On-line Table 2). A good functional outcome (median mRS $\leq 2$ ) at last follow-up was recorded in 49 patients (60\%); a poor outcome (median mRS 3-6), in 33 patients (40\%), with no statistically significant difference between the 2 cohorts $(P=.82)$. Persistent disabilities requiring constant nursing care (mRS $4-5$ ) were noted in 4 patients ( $8 \%$ ) with $\leq 2$ interventions and in $3(10 \%)$ of those with $\geq 3$ interventions. Overall mortality (mRS 6) was $20 \%$, with no differences between the 2 cohorts $(P=.31)$.

Sixty-one percent of patients rated headache/fatigue and $39 \%$, a persisting neurologic deficit as the most disturbing long-term effect. In patients with $\geq 3$ interventions, none of the working-age patients were able to work full-time at longterm follow-up, $42 \%$ worked part-time either in the same or another profession, $23 \%$ had no employment, and early retirement was taken by $3 \%$. In contrast, in patients with $\leq 2$ interventions, 5 (6\%) of the working-age patients were able to work full-time, whereas $6(13 \%)$ worked part-time either in the same or another profession. Sixteen (33\%) patients had no employment at last follow-up.

The following variable was associated with a good functional outcome (median mRS 0-2) at last follow-up (Table 3): Hunt and Hess scale of $\leq 2$ (OR, 7.6; 95\% CI, 2.7-22.3; $P<.001$ ), whereas new cerebral infarctions (OR, 14.8; 95\% CI, 3.9-55.3; $P<.001$ ) and infarction in eloquent areas (OR, 26.0; 95\% CI, 7.7-88.2; $P<$
.001) were associated with a poor outcome (median mRS $>2$ ). Multivariable analysis revealed the $\mathrm{HH}$ scale score of $\leq 2(\mathrm{OR}, 4.7 ; 95 \% \mathrm{CI}, 1.2-18.5 ; P=.03)$ as an independent predictor of favorable functional outcome ( $\mathrm{mRS} \leq 2)$ and infarcts in eloquent areas (OR, 13.5; 95\% CI, 2.3-81.2; $P=.004)$ as an independent risk factor for poor outcome (mRS 3-6) at last follow-up.

\section{Cerebral Infarctions}

Assessments of new infarcted areas and infarcts in eloquent regions are shown in Table 2 and On-line Table 2. New infarcted areas at discharge were registered in $23(74 \%)$ patients with $\geq 3$ interventions compared with $26(52 \%)$ patients with $\leq 2$ interventions $(P=.06)$. There was no difference between the 2 cohorts regarding infarcts located in eloquent brain areas, which were observed in 17 (55\%) patients with $\geq 3$ interventions versus $18(37 \%)$ patients with $\leq 2$ interventions $(P=.17)$. We identified the following risk factors associated with infarction at discharge (Table 4): number of treatments (OR, 1.4; 95\% CI, 1.0-1.9; $P=.05)$, number of vessels treated (OR, 1.2 ; 95\% CI, $1.0-1.4 ; P=.03)$, and requirement for PTA (OR, 2.7; 95\% CI, 1.07.9; $P=.06)$. Multivariable analysis revealed the $\mathrm{HH}$ scale score of $\geq 3$ (OR, 3.4; $95 \% \mathrm{CI}, 1.2-9.3 ; P=.02)$ and the number of vascular territories treated (OR, 3.1;95\% CI, 1.3-7.3; $P=.01)$ as independent predictors of infarcts at discharge.

\section{Treatment-Related Morbidity and Mortality}

There was no treatment-related mortality. Complications resulting from aneurysm obliteration procedures consisted of 2 (2\%) patients with thrombosis of the parent vessel during coil embolization, which dissolved following intra-arterial thrombolytic therapy. In 1 patient (1\%), aneurysm rerupture during coil embolization occurred but did not result in a clinical decline.

Complications resulting from spasmolysis therapies consisted of dissection in the access vessel of the ICA in $1(2 \%)$ patient with $\leq 2$ interventions versus $5(16 \%)$ patients with $\geq 3$ interventions $(P=.03)$, requiring stent placement for persistent high-grade stenosis in 1 patient. Another patient (1\%) developed a pseudoaneurysm at the puncture side of the femoral artery.

\section{DISCUSSION}

IAN offers some last resort treatment strategies, yet application generally remains limited to 1 or 2 or, at most, 3 interventions. ${ }^{20-23}$ Cases of patients undergoing $>3$ endovascular interventions in response to persistent, recurrent, or worsening CVS have seldom been described, and results on functional outcome remain ambiguous. ${ }^{24}$ Jun et $\mathrm{al}^{25}$ reported a subgroup of patients 
Table 3: Factors associated with good functional outcome (mRS $\leq 2$ ) at last follow-up

\begin{tabular}{|c|c|c|c|c|}
\hline $\begin{array}{l}\text { Predictors for Good } \\
\text { Outcome (mRS <2) }\end{array}$ & $\begin{array}{l}\text { Univariable Analyses } \\
\text { (OR) }(95 \% \mathrm{Cl})\end{array}$ & $P$ Value & $\begin{array}{c}\text { Multivariable } \\
\text { Analyses } \\
\text { (OR) }(95 \% \mathrm{CI})\end{array}$ & $P$ Value \\
\hline No. of treatments & $0.995(0.77-1.29)$ & .969 & & \\
\hline Male sex & $1.816(0.57-5.75)$ & .31 & & \\
\hline Age (yr) & $0.961(0.92-1.01)$ & .084 & & \\
\hline Aneurysm, anterior location & $0.749(0.29-1.92)$ & .547 & & \\
\hline Further aneurysms & $1.161(0.46-2.94)$ & .752 & & \\
\hline Aneurysm obliteration, clip & $0.568(0.22-1.49)$ & .249 & & \\
\hline $\mathrm{HH}$ scale $\leq 2$ & 7.75 (2.69-22.33) & $<.001$ & $4.72(1.21-18.48)$ & .026 \\
\hline Infarcts in eloquent areas & $0.038(0.01-0.13)$ & $<.001$ & $0.074(0.012-0.443)$ & .004 \\
\hline No. of vessels treated & $0.965(0.89-1.05)$ & .421 & & \\
\hline No. of vascular territories & $0.594(0.33-1.07)$ & .082 & & \\
\hline PTA & $0.7(0.27-1.79)$ & .458 & & \\
\hline Brain infarcts & $0.069(0.02-0.25)$ & $<.001$ & $0.359(0.04-3.08)$ & .35 \\
\hline Age younger than $50 \mathrm{yr}$ & $1.66(0.62-4.47)$ & .316 & & \\
\hline Length of FU (mo) & $1.01(0.95-1.07)$ & .72 & & \\
\hline
\end{tabular}

Note:-FU indicates follow-up.

Table 4: Risk factors associated with infarction at discharge

\begin{tabular}{lcccc}
$\begin{array}{c}\text { Risk Factors for Infarcts } \\
\text { at Discharge }\end{array}$ & $\begin{array}{c}\text { Univariable Analyses } \\
(\text { OR) }(95 \% \text { CI) }\end{array}$ & $\begin{array}{c}\text { Multivariable } \\
\text { Analyses }\end{array}$ & \\
\hline Age (yr) & $0.99(0.95-1.0)$ & .646 & & \\
Female sex & $1.23(0.41-3.77)$ & .699 & & \\
Aneurysm, anterior location & $1.76(0.70-4.45)$ & .23 & & \\
Further aneurysms & $0.97(0.39-2.43)$ & .944 & & \\
Aneurysm obliteration, clip & $1.73(0.62-4.85)$ & .296 & & .02 \\
HH scale $\geq 3$ & $3.14(1.24-7.92)$ & .016 & $3.35(1.21-9.30)$ & .469 \\
No. of treatments & $1.39(1.00-1.94)$ & .049 & $1.28(0.66-2.46)$ & .0161 \\
No. of vessels treated & $1.17(1.01-1.36)$ & .034 & $0.93(0.73-1.19)$ & .561 \\
No. of vascular territories & $2.91(1.49-5.64)$ & .002 & $3.08(1.30-7.30)$ & .011 \\
PTA & $2.74(0.95-7.90)$ & .061 & & \\
Age younger than 50 yr & $0.81(0.30-2.14)$ & .807 & & \\
\hline
\end{tabular}

indeed effective in treating proximal artery vasospasms and results in more durable clinical improvement. ${ }^{25,33,34}$ However, in smaller and more distal vessels, this technique is limited by the possibility of vessel rupture. ${ }^{27}$ For more distal or diffuse vasospasms with reduced parenchymal perfusion, several superselective intra-arterial agents have been shown to be effective though transient. ${ }^{35}$ A number of clinical studies regarding the effect of intra-arterial nimodipine in patients with severe refractory CVS exist $^{8,9,36}$; however, some controversy remains as to the effectiveness of IAN. ${ }^{37}$ Furthermore, these reports comprise mostly small, retrospective case series. ${ }^{38}$

While we noted a good clinical outcome in $61 \%$ of patients with $\leq 2$ interventions versus $58 \%$ with $\geq 3$ interventions $(P=.82)$ after a median follow-up of $10 \pm 8$ months, $70 \%$ of patients recruited for the Barrow Ruptured Aneurysm Trial (BRAT) showed good functional outcome after 1 year, ${ }^{39} 67 \%$ after 3 years, ${ }^{40}$ and $62 \%$ after 6 years following $\mathrm{SAH}^{41}$

In patients recruited for the International Subarachnoid Aneurysm Trial (ISAT), an $\mathrm{mRS}$ of $\leq 2$ after 1 year was reported in $72.8 \%$ of them and in $70.2 \%$ 8 years later. ${ }^{42-44}$ However, the BRAT

$(6 \%, 12$ of 189$)$ with rCVS who underwent $\geq 3$ endovascular interventions, and Pandey et al, ${ }^{26}$ a subgroup of $7 \%$ of patients ( 2 of 27); but no functional outcome was reported in this subgroup of patients. Most interesting, in the study by Pandey et al, nicardipine was infused through a cervical catheter, with selective catheterization and angioplasty reserved for refractory cases, thereby reducing the risk related to microcatheterization itself. ${ }^{26}$ In their series, no complications attributed to the angiographic interventions were described. Given that the rate of cervical artery dissections was higher than that recorded in other studies, ${ }^{25,27}$ less aggressive approaches might be considered in selected cases.

Due to the transient vasodilatory effects of IAN, ${ }^{23,28-31} \mathrm{Al}-$ banese et $\mathrm{al}^{7}$ reported prevention of new ischemic events in 9 of 12 patients with prolonged intra-arterial infusion of verapamil. However, catheterization over an extended period might increase the risk of thrombus formation and subsequent embolisms. ${ }^{29}$ Additionally, it generally involves different personnel in the intensive care unit, thereby increasing the risk of air embolism by manipulating the perfusion system. Indeed, repeat endovascular procedures via microcatheterization had greater risks for related complications but also allowed immediate initiation of endovascular therapies, which has been shown to markedly improve outcome compared with patients whose treatment was delayed. ${ }^{32}$

Depending on the location and severity of the CVS, either PTA or IAN can be used in the clinical setting. Balloon angioplasty is and ISAT trials represent the full range of patients, including those with a good-grade $\mathrm{SAH},{ }^{45}$ thus not reflecting the subpopulation at highest risk for refractory CVS with subsequent infarction and poor quality of life. ${ }^{46}$

Most important, a poor neurologic outcome (mRS 4 or 5) with persistent disabilities requiring constant nursing care could be prevented in most patients. Pegoli et al ${ }^{46}$ noted an excellent outcome (mRS $0-1$ ) in $63 \%$ of patients with aneurysmal SAH; however, symptomatic CVS and consecutive infarctions were risk factors for poor outcome. ${ }^{46,47}$

As many as $91 \%$ of patients with poor quality of life following $\mathrm{SAH}$ failed to return to full-time work. ${ }^{48}$ Aneurysmal SAH is a cerebrovascular disease particularly affecting the younger working-age population, thereby increasing the economic burden for numerous patients, their families, and society as a whole. ${ }^{49,50}$ At last follow-up, only $6 \%$ of patients worked full-time, $24 \%$ of patients worked part-time, and 29\% were unemployed. Our results are in line with these earlier findings. Indeed, vasospasm-related delayed ischemic neurologic deficits and cerebral infarction are strongly associated with unfavorable outcomes following SAH. ${ }^{15,51,52}$ While cerebral or angiographic vasospasm is a treatable condition, the effectiveness of nimodipine, hemodynamic therapy, and endovascular interventions, including angioplasty, in preventing neurologic deficits remains controversial. ${ }^{53-55}$

In summary, our approach of immediate repeat endovascular interventions in patients with the most severe CVS refractory to 
traditional therapies resulted in a favorable outcome in about two-thirds of patients and prevented severe disability in most of them. However, it remains difficult to assess whether immediate endovascular treatments ultimately result in a better neurologic outcome because vasospasm is not the only cause of delayed ischemic complications. ${ }^{56}$

Nevertheless, rescue therapies to reduce the impact of rCVS following SAH might be beneficial in devastating cases. On the basis of the current data and from the experience we gained from performing these procedures in this subpopulation of patients at highest risk for refractory CVS, we think that it is important to continue the effort to treat even those patients who are refractory to 1 or 2 endovascular interventions, even when little or no effect and ongoing cerebral vasospasm are evident. Large multicenter, prospective, randomized controlled studies are, however, needed to prove the effectiveness of repeat instant endovascular interventions in patients with refractory cerebral vasospasms-not an easy undertaking given the ethical problems of withholding therapeutic interventions, even if the effect of the therapy remains ambiguous. At present, treatment of rCVS with immediate multiple endovascular interventions is feasible and safe and may be warranted until the significance of these interventions becomes better understood.

\section{Study Limitations}

Assessment of cerebral infarctions by CT in 36\% of all patients may actually lower the true rate of radiographically detected cerebral infarctions, given the higher sensitivity of MR imaging in detecting vasospasm-related infarction. ${ }^{17}$ In addition, a median follow-up of $10 \pm 7.0$ months may under-represent the true rate of poor outcome, considering longer term outcome studies that showed a steady increase in patients with poor outcome across time. ${ }^{39,41}$

\section{CONCLUSIONS}

The use of immediate repeat endovascular interventions is an aggressive but feasible last resort treatment strategy effective for a selected subgroup of patients who fail to respond to traditional CVS therapies and endovascular interventions.

\section{ACKNOWLEDGMENTS}

The assistance of Ms Susan Kaplan in preparing this manuscript is acknowledged. We wish to thank Dr Corrado Bernasconi for statistical advice.

Disclosures: Lukas Andereggen—UNRELATED: Grants/Grants Pending: Swiss National Science Foundation. Werner Z'Graggen—UNRELATED: Employment: Bern University Hospital. Gerhard Schroth—UNRELATED: Employment: Bern University Hospital, Comments: normal salary as a $50 \%$ senior consultant of the University Institute for Diagnostic and Interventional Neuroradiology of Bern University Hospital Inselspital; Grants/Grants Pending: Swiss National Science Foundation, Comments: grant for neuropsychological investigations before and after carotid stenting*; Payment for Lectures including Service on Speakers Bureaus: European Stroke Organisation, Master Course at the Danube University in Krems, Austria, Comments: lectures and hands-on workshops; money paid exclusively to the Inselspital. Michael Reinert-UNRELATED: Consultancy: Brainlab, DePuys Synthes*; Employment: Ente Ospedaliero Cantonale Ticino; Grants/Grants Pending: Lega Ticinesi contro il Cancro*; Payment for Lectures including Service on Speakers Bureaus: Brainlab.* Jan Gralla—UNRELATED: Consultancy: Covidien, Comments: former Global Principal Investigator for the Star Study on thrombectomy in acute stroke, consultant for Covidien.* *Money paid to the institution.

\section{REFERENCES}

1. Naidech AM, Drescher J, Tamul P, et al. Acute physiological derangement is associated with early radiographic cerebral infarction after subarachnoid haemorrhage. J Neurol Neurosurg Psychiatry 2006;77:1340-44 CrossRef Medline

2. van Gijn J, Kerr RS, Rinkel GJ. Subarachnoid haemorrhage. Lancet 2007;369:306-18 CrossRef Medline

3. Kassell NF, Sasaki T, Colohan AR, et al. Cerebral vasospasm following aneurysmal subarachnoid hemorrhage. Stroke 1985;16:562-72 CrossRef Medline

4. Platz J, Guresir E, Vatter H, et al. Unsecured intracranial aneurysms and induced hypertension in cerebral vasospasm: is induced hypertension safe? Neurocrit Care 2011;14:168-75 CrossRef Medline

5. Frontera JA, Fernandez A, Schmidt JM, et al. Defining vasospasm after subarachnoid hemorrhage: what is the most clinically relevant definition? Stroke 2009;40:1963-68 CrossRef Medline

6. Kimball MM, Velat GJ, Hoh BL. Critical care guidelines on the endovascular management of cerebral vasospasm. Neurocrit Care 2011;15:336-41 CrossRef Medline

7. Albanese E, Russo A, Quiroga M, et al. Ultrahigh-dose intraarterial infusion of verapamil through an indwelling microcatheter for medically refractory severe vasospasm: initial experience-clinical article. J Neurosurg 2010;113:913-22 CrossRef Medline

8. Biondi A, Ricciardi GK, Puybasset L, et al. Intra-arterial nimodipine for the treatment of symptomatic cerebral vasospasm after aneurysmal subarachnoid hemorrhage: preliminary results. AJNR Am J Neuroradiol 2004;25:1067-76 Medline

9. Hängg D, Turowski B, Beseoglu K, et al. Intra-arterial nimodipine for severe cerebral vasospasm after aneurysmal subarachnoid hemorrhage: influence on clinical course and cerebral perfusion. AJNR Am J Neuroradiol 2008;29:1053-60 CrossRef Medline

10. Komotar RJ, Zacharia BE, Otten ML, et al. Controversies in the endovascular management of cerebral vasospasm after intracranial aneurysm rupture and future directions for therapeutic approaches. $\mathrm{Neu}$ rosurgery 2008;62:897-905; discussion 905-897 CrossRef Medline

11. Dankbaar JW, de Rooij NK, Rijsdijk M, et al. Diagnostic threshold values of cerebral perfusion measured with computed tomography for delayed cerebral ischemia after aneurysmal subarachnoid hemorrhage. Stroke 2010;41:1927-32 CrossRef Medline

12. Beck J, Raabe A, Lanfermann H, et al. Tissue at risk concept for endovascular treatment of severe vasospasm after aneurysmal subarachnoid haemorrhage. J Neurol Neurosurg Psychiatry 2004;75: 1779-81 CrossRef Medline

13. Beck J, Raabe A, Lanfermann H, et al. Effects of balloon angioplasty on perfusion- and diffusion-weighted magnetic resonance imaging results and outcome in patients with cerebral vasospasm. J Neurosurg 2006;105:220-27 CrossRef Medline

14. Vatter H, Güresir E, Berkefeld J, et al. Perfusion-diffusion mismatch in MRI to indicate endovascular treatment of cerebral vasospasm after subarachnoid haemorrhage. J Neurol Neurosurg Psychiatry 2011;82:876-83 CrossRef Medline

15. Vergouwen MD, Ilodigwe D, Macdonald RL. Cerebral infarction after subarachnoid hemorrhage contributes to poor outcome by vasospasm-dependent and -independent effects. Stroke 2011;42: 924-29 CrossRef Medline

16. Janssen PM, Visser NA, Dorhout Mees SM, et al. Comparison of telephone and face-to-face assessment of the modified Rankin Scale. Cerebrovasc Dis 2010;29:137-39 CrossRef Medline

17. Shimoda M, Takeuchi M, Tominaga J, et al. Asymptomatic versus symptomatic infarcts from vasospasm in patients with subarachnoid hemorrhage: serial magnetic resonance imaging. Neurosurgery 2001;49:1341-48; discussion 1348-50 CrossRef Medline

18. Hunt WE, Hess RM. Surgical risk as related to time of intervention in the repair of intracranial aneurysms. J Neurosurg 1968;28:14-20 CrossRef Medline

19. Fisher CM, Kistler JP, Davis JM. Relation of cerebral vasospasm to subarachnoid hemorrhage visualized by computerized tomographic scanning. Neurosurgery 1980;6:1-9 CrossRef Medline 
20. Aburto-Murrieta Y, Marquez-Romero JM, Bonifacio-Delgadillo D, et al. Endovascular treatment: balloon angioplasty versus nimodipine intra-arterial for medically refractory cerebral vasospasm following aneurysmal subarachnoid hemorrhage. Vasc Endovasc Surg 2012;46:460-65 CrossRef Medline

21. John S, Spiotta AM, Turner RM, et al. Initial experience with the coaxial dual-lumen Scepter C balloon catheter for endovascular management of cerebral vasospasm from subarachnoid hemorrhage. J Neurointerv Surg 2014;6:125-28 CrossRef Medline

22. Santillan A, Knopman J, Zink W, et al. Transluminal balloon angioplasty for symptomatic distal vasospasm refractory to medical therapy in patients with aneurysmal subarachnoid hemorrhage. Neurosurgery 2011;69:95-101; discussion 102 CrossRef Medline

23. Wolf S, Martin H, Landscheidt JF, et al. Continuous selective intraarterial infusion of nimodipine for therapy of refractory cerebral vasospasm. Neurocrit Care 2010;12:346-51 CrossRef Medline

24. Mortimer AM, Steinfort B, Faulder K, et al. Institution of sustained endovascular treatment prior to clinical deterioration in patients with severe angiographic vasospasm: A retrospective observational study of clinico-radiological outcomes. J Neuroradiol 2015;42: 176-83 CrossRef Medline

25. Jun P, Ko NU, English JD, et al. Endovascular treatment of medically refractory cerebral vasospasm following aneurysmal subarachnoid hemorrhage. AJNR Am J Neuroradiol 2010;31:1911-16 CrossRef Medline

26. Pandey P, Steinberg GK, Dodd R, et al. A simplified method for administration of intra-arterial nicardipine for vasospasm with cervical catheter infusion. Neurosurgery 2012;71(1 suppl operative): 77-85 CrossRef Medline

27. Zwienenberg-Lee M, Hartman J, Rudisill N, et al; Balloon Prophylaxis for Aneurysmal Vasospasm (BPAV) Study Group. Effect of prophylactic transluminal balloon angioplasty on cerebral vasospasm and outcome in patients with Fisher grade III subarachnoid hemorrhage: results of a phase II multicenter, randomized, clinical trial. Stroke 2008;39: 1759-65 CrossRef Medline

28. Doukas A, Petridis AK, Barth H, et al. Resistant vasospasm in subarachnoid hemorrhage treated with continuous intraarterial nimodipine infusion. Acta Neurochir Suppl 2011;112:93-96 CrossRef Medline

29. Musahl C, Henkes H, Vajda Z, et al. Continuous local intra-arterial nimodipine administration in severe symptomatic vasospasm after subarachnoid hemorrhage. Neurosurgery 2011;68:1541-47; discussion 1547 CrossRef Medline

30. Feng L, Fitzsimmons BF, Young WL, et al. Intraarterially administered verapamil as adjunct therapy for cerebral vasospasm: safety and 2-year experience. AJNR Am J Neuroradiol 2002;23:1284-90 Medline

31. Keuskamp J, Murali R, Chao KH. High-dose intraarterial verapamil in the treatment of cerebral vasospasm after aneurysmal subarachnoid hemorrhage. J Neurosurg 2008;108:458-63 CrossRef Medline

32. Rosenwasser RH, Armonda RA, Thomas JE, et al. Therapeutic modalities for the management of cerebral vasospasm: timing of endovascular options. Neurosurgery 1999;44:975-79; discussion 979-80 CrossRef Medline

33. Khatri $\mathrm{R}$, Memon MZ, Zacharatos $\mathrm{H}$, et al. Impact of percutaneous transluminal angioplasty for treatment of cerebral vasospasm on subarachnoid hemorrhage patient outcomes. Neurocrit Care 2011; 15:28-33 CrossRef Medline

34. Pandey AS, Elias AE, Chaudhary N, et al. Endovascular treatment of cerebral vasospasm: vasodilators and angioplasty. Neuroimaging Clin N Am 2013;23:593-604 CrossRef Medline

35. Rahme R, Jimenez L, Pyne-Geithman GJ, et al. Endovascular management of posthemorrhagic cerebral vasospasm: indications, technical nuances, and results. Acta Neurochir Suppl 2013;115: 107-12 CrossRef Medline

36. Hui C, Lau KP. Efficacy of intra-arterial nimodipine in the treatment of cerebral vasospasm complicating subarachnoid haemorrhage. Clin Radiol 2005;60:1030-36 CrossRef Medline

37. Firat MM, Gelebek V, Orer HS, et al. Selective intraarterial nimodipine treatment in an experimental subarachnoid hemorrhage model. AJNR Am J Neuroradiol 2005;26:1357-62 Medline
38. Hoh BL, Ogilvy CS. Endovascular treatment of cerebral vasospasm: transluminal balloon angioplasty, intra-arterial papaverine, and intra-arterial nicardipine. Neurosurg Clin N Am 2005;16:501-16, vi Medline

39. McDougall CG, Spetzler RF, Zabramski JM, et al. The Barrow Ruptured Aneurysm Trial. J Neurosurg 2012;116:135-44 CrossRef Medline

40. Spetzler RF, McDougall CG, Albuquerque FC, et al. The Barrow Ruptured Aneurysm Trial: 3-year results. J Neurosurg 2013;119:146-57 CrossRef Medline

41. Spetzler RF, McDougall CG, Zabramski JM, et al. The Barrow Ruptured Aneurysm Trial: 6-year results. J Neurosurg 2015;123:609-17 CrossRef Medline

42. Molyneux A, Kerr R, Stratton I, et al; International Subarachnoid Aneurysm Trial (ISAT) Collaborative Group. International Subarachnoid Aneurysm Trial (ISAT) of neurosurgical clipping versus endovascular coiling in 2143 patients with ruptured intracranial aneurysms: a randomised trial. Lancet 2002;360:1267-74 CrossRef Medline

43. Molyneux AJ, Kerr RS, Birks J, et al; ISAT Collaborators. Risk of recurrent subarachnoid haemorrhage, death, or dependence and standardised mortality ratios after clipping or coiling of an intracranial aneurysm in the International Subarachnoid Aneurysm Trial (ISAT): longterm follow-up. Lancet Neurol 2009;8:427-33 CrossRef Medline

44. Molyneux AJ, Kerr RS, Yu LM, et al; International Subarachnoid Aneurysm Trial (ISAT) Collaborative Group. International subarachnoid aneurysm trial (ISAT) of neurosurgical clipping versus endovascular coiling in 2143 patients with ruptured intracranial aneurysms: a randomised comparison of effects on survival, dependency, seizures, rebleeding, subgroups, and aneurysm occlusion. Lancet 2005;366:809-17 CrossRef Medline

45. Darsaut TE, Jack AS, Kerr RS, et al. International Subarachnoid Aneurysm Trial-ISAT, Part II: study protocol for a randomized controlled trial. Trials 2013;14:156 CrossRef Medline

46. Pegoli M, Mandrekar J, Rabinstein AA, et al. Predictors of excellent functional outcome in aneurysmal subarachnoid hemorrhage. J Neurosurg 2015;122:414-18 CrossRef Medline

47. Hänggi D, Etminan N, Macdonald RL, et al. NEWTON: Nimodipine Microparticles to Enhance Recovery While Reducing Toxicity After Subarachnoid Hemorrhage. Neurocrit Care 2015;23:274-84 CrossRef Medline

48. Taufique Z, May T, Meyers E, et al. Predictors of poor quality of life 1 year after subarachnoid hemorrhage. Neurosurgery 2016;78: 256-56 CrossRef Medline

49. Dodel R, Winter Y, Ringel F, et al. Cost of illness in subarachnoid hemorrhage: a German longitudinal study. Stroke 2010;41:2918-23 CrossRef Medline

50. Sehba FA, Hou J, Pluta RM, et al. The importance of early brain injury after subarachnoid hemorrhage. Prog Neurobiol 2012;97: 14-37 CrossRef Medline

51. Fergusen S, Macdonald RL. Predictors of cerebral infarction in patients with aneurysmal subarachnoid hemorrhage. Neurosurgery 2007;60:658-67; discussion 667 Medline

52. Rosengart AJ, Huo JD, Tolentino J, et al. Outcome in patients with subarachnoid hemorrhage treated with antiepileptic drugs. J Neurosurg 2007;107:253-60 CrossRef Medline

53. Bederson JB, Connolly ES Jr, Batjer HH, et al; American Heart Association. Guidelines for the management of aneurysmal subarachnoid hemorrhage: a statement for healthcare professionals from a special writing group of the Stroke Council, American Heart Association. Stroke 2009;40:994-1025 CrossRef Medline

54. Dorhout Mees SM, Rinkel GJ, Feigin VL, et al. Calcium antagonists for aneurysmal subarachnoid haemorrhage. Cochrane Database Syst Rev 2007:CD000277 Medline

55. Rabinstein AA, Lanzino G, Wijdicks EF. Multidisciplinary management and emerging therapeutic strategies in aneurysmal subarachnoid haemorrhage. Lancet Neurol 2010;9:504-19 CrossRef Medline

56. Budohoski KP, Czosnyka M, Kirkpatrick PJ, et al. Clinical relevance of cerebral autoregulation following subarachnoid haemorrhage. Nat Rev Neurol 2013;9:152-63 CrossRef Medline 